\title{
Butyltin compounds in a sediment core from the old Tilbury basin, London, UK.
}

\author{
M. D. Scrimshaw ${ }^{1}$, R. Wahlen ${ }^{2}$, T. Catterick ${ }^{2}$ and J. N. Lester ${ }^{1} *$
}

${ }^{1}$ Department of Environmental Science and Technology, Faculty of Life Sciences, Imperial College London, London SW7 2 AZ.

${ }^{2}$ LGC Ltd., Queens Road, Teddington, Middlesex, TW11 OLY

* Corresponding author. Tel.: +44 (0)20 7594 6014; fax: +44 (0)20 7594 6016. E-mail address:
j.lester@imperial.ac.uk

\begin{abstract}
Sections from a sediment core taken from the River Thames were analysed for butyl tin species using gas chromatography with species-specific isotope dilution mass spectrometry. Results demonstrated that in most samples tributyltin concentrations of $20-60 \mathrm{ng} / \mathrm{g}$ accounted for $<10 \%$ of the total butyl tin species present, which is in agreement with data from other sediment samples which were historically contaminated with tributyltin. Vertical distribution of the organotin residues with depth throughout the core, with data on organochlorine compounds and heavy metals allowed for the construction of a consistent hypothesis on historical deposition of contaminated sediments. From this it was possible to infer that the concentrations of tributyltin in sediments deposited during the early 1960s were in the order of 400 $-600 \mu \mathrm{g} / \mathrm{g}$ by using degradation rate constants derived by other workers. Such values fall well within the range quoted for harbour sediments in the literature.
\end{abstract}

Keywords: Tributyltin; Antifoulant; Isotope dilution; Gas chromatography; Inductively Coupled Plasma Mass Spectrometry

\section{Introduction}

During the past two decades, organotin compounds have been the focus of much research and concern, however, as late as 1983 the opinion that they were "unlikely to create a serious longterm pollution hazard" was still being expressed (Bennett, 1983). Such conclusions were predominantly based on degradation studies, although it was recognised that problems remained in determining their fate in environmental samples (Blunden and Chapman, 1982). These views were in conflict with evidence of environmental effects, which had already resulted in a partial, temporary, ban on the use of tributyltin (TBT) in antifoulants in France by January 1982 (Alzieu, 2000). The French Temporary Ban, as it became known, resulted in a rapid return to oyster farming in affected areas, within 1 year spatfall was normal and over the next two years shell 
anomalies declined (Alzieu, 1991). As the 1980s progressed, organtin compounds were implicated as causal agents for a range of effects on a number of marine organisms and restrictions on their use became more widespread, and have resulted in the recovery of populations of dog whelk (Evans et al., 1996) and reduction of impacts on oyster farming (Alzieu, 2000). Elsewhere, bans on the use of TBT based antifoulants on vessels of $<25 \mathrm{~m}$ in length resulted in decreases in concentrations of butyltin compounds in marinas and recreational estuaries (Dowson et al., 1993; Dowson et al., 1994). However, in areas where larger vessels continue to use TBT based treatments the occurrence of imposex in molluscs remains a concern (Horiguchi et al., 2004).

It was not until the 1950s that the use of organotin compounds (predominantly di and mono-alkyl compounds) had found significant industrial use, initially as stabilisers in the plastics industry (Bennett, 1983). The use of TBT as a fungicide and biocide, in particular for use in antifouling paints, began in Europe between 1959 and 1961 (Clark et al., 1988). Due to the organic groups conferring hydrophobic nature, organotin compounds demonstrate an affinity for particulate matter once they enter the environment. Between 57 and $95 \%$ of TBT in the water column was shown to partition to the solid phase in estuarine conditions (Randall and Weber, 1986), although increases in salinity have been observed to reduce sorption to sediments (Unger et al., 1988). Once deposited in bed sediments, TBT demonstrates greater persistence than in surface material (Batley, 1996; Dowson et al., 1996)

The fact that contamination of sediments by organotins may pose a threat to marine biota long after release of the substances has been noted and the study of degradation compounds in cores has been utilised to determine rates of transformation of the parent compound (Almeida et al., 2004). As a result of their slow degradation, the possible presence of TBT residues in sediments needs to be taken into account when assessing sediment quality, and recent evaluations undertaken at Port Curtis, Australia, demonstrated that elevated concentrations of TBT in sediments and water may be of ecological concern due to uptake by biota (Jones et al., 2005). The chronic toxicity of TBT to biota and the relationship between toxicity and bioaccumulation has been identified as a tool for predicting the toxicity of contaminated sediments (Bartlett et al., 2004) and the availability of sediment bound TBT to biota, as demonstrated by uptake and effects, is supported by other studies (Midorikawa et al., 2004; Ramaswamy et al., 2004). Contamination with TBT may effect a range of organisms, and although effects on molluscs are well documented, corals have also been identified as being impacted by TBT (Smith et al., 2003) indicating that understanding the fate and behavior of residues of TBT is likely to be significant in protecting a wide range of ecosystems. 
Residues of TBT in sediments, therefore, continue to present a potential hazard to biota and indications that their longevity may be greater than previously thought, with half lives of up to 87 years in cold, deep sediments (Viglino et al., 2004), would imply that the risk of exposure will remain for some time after their use is phased out. The objective of this work was to utilize a recently developed and well validated analytical technique on a set of samples taken from a sediment core retrieved from the River Thames in 1994. It was anticipated that this would give some insights into the historical deposition of butyltins in the bed sediments and allow for a greater understanding of the long term persistence of residues. Such information is likely to be of use in areas where contaminated bed sediments may be re-worked by storm events or anthropogenic activity.

\section{Materials and methods.}

The collection of the core used for this study and the dating of the core material has been described in detail (Scrimshaw and Lester, 1997; Wiese et al., 1997), with the samples analyzed here taken from core 1. The sampling location (Fig. 1), the old Tilbury basin was constructed in 1880 in the lower-mid part of the Thames estuary, a zone of high-turbidity with intermediate salinities of 11-15 practical salinity units (psu) (Harino et al., 2003). Initially, the basin was built to provide access to the main docks, but this function ceased when a new lock entrance was constructed in 1929. The data on soundings within the Basin were collected from the Port of London Authority Hydrographic Department at Gravesend and frequent dredging operations took place after monthly soundings, but no record of the depth to which the Basin was actually dredged exist. The data consisted of charts of soundings surveys for the Tidal Basin and abstracts from the following years: 1916, 1944 and 1965-93 were taken, with 1916 and 1944 selected to give a historical perspective and 1965 onwards to allow an evaluation of changes since dredging ceased.

To assess deposition rates, 9 sounding points on a $17 \mathrm{~m}$ by $4 \mathrm{~m}$ grid were selected close to the location of core 7. Sounding depths were found for each point on the grid from each sounding survey or by interpolation where necessary. These were converted to elevations above OD with the construction depth of $9.5 \mathrm{~m}$ below ordnance datum (OD) (Greeves, 1980). Ordnance Datum is the mean sea level at Newlyn measured over a six year period during the 1920's as defined for the Government Survey of Great Britain. From 1945, the basin underwent limited dredging until early 1965 when dredging ceased, with accumulation of sediments decreasing from around $3 \mathrm{~m} / \mathrm{yr}$ (1966) to $0.08 \mathrm{~m} / \mathrm{yr}$ (1966- 67) to $0.01 \mathrm{~m} / \mathrm{yr}$ (1968 to present) with continuous reworking of the upper $1 \mathrm{~m}$ of material. High rates of deposition within the basin are reflected in dredging 
frequency and are a result of its location on the inside of a bend in the river subject to slack heavily silted water (Broodbank 1921).

\subsection{Organotin speciation in surface and sub-surface sediments}

Stored, frozen samples were air-dried and ground prior to extraction and in addition to the sediment samples from the Tilbury core, several sub-samples of a certified reference sediment (PACS-2) were also analysed. Polycarbonate chips from the core liner material and extraction blanks were also taken through the analytical procedure.

The analytical method used for extraction, derivatisation and quantification has been described in detail elsewhere (Wahlen and Wolff-Briche, 2003). Samples of approximately $1.6 \mathrm{~g}$ dry weight were weighed into $11 \mathrm{ml}$ accelerated solvent extraction (ASE) cells fitted with PTFE liners and filled with a diatomaceous dispersing agent. The sample was mixed with the dispersing agent and spiked with $100 \mu$ l of the isotopically labeled ${ }^{117} \mathrm{Sn}$ DBT and TBT analogues. The samples were then extracted by ASE and extracts derivatised using sodiumtetraethylborate (STEB). A 1M sodium acetate buffer was prepared to adjust the extracts to $\mathrm{pH} 4.5-5.0$. A volume of $5 \mathrm{ml}$ of the sample extracts was added to $5 \mathrm{~mL}$ of the buffer solution and $2 \mathrm{ml}$ of hexane and $1 \mathrm{ml}$ of $2 \%$ STEB in amber screw-capped glass vials. The mixture was shaken manually for 10 minutes and the organic and aqueous phases were allowed to separate. The hexane layer was then transferred into a $\mathrm{GC}$ autosampler vial for analysis. The hexane fractions were stored in the fridge at $4^{\circ} \mathrm{C}$ if they could not be analyzed immediately. Quantification was by GC-ICP-MS, with the instrumental detection limits based on 3 times the standard deviation of the blank signal $(3 \sigma)$ for each analyte were estimated as $0.25 \mathrm{ng} / \mathrm{g}$ for MBT, $0.03 \mathrm{ng} / \mathrm{g}$ for DBT and $0.03 \mathrm{ng} / \mathrm{g}$ for TBT (all as $\mathrm{Sn}$ ). Using typical sample weights and dilution factors the corresponding method detection limits obtained were $6.1 \mathrm{ng} / \mathrm{g}$ for MBT, $0.7 \mathrm{ng} / \mathrm{g}$ for DBT and $0.8 \mathrm{ng} / \mathrm{g}$ for TBT (all as $\mathrm{Sn}$ ).

Quantification for the CRM, PACS-2, for DBT and TBT compared well with the certified values of $1090 \pm 150 \mathrm{ng} / \mathrm{g}$ and $980 \pm 130 \mathrm{ng} / \mathrm{g}$ as Sn respectively (Table 1). These two compounds were quantified using species-specific isotope dilution analysis (SS-IDMS) and the IDMS approach used has been tested with good results in a number of international inter-comparison studies with other expert laboratories (Sturgeon and Wahlen, 2002; Sturgeon et al., 2003). The method has not been tested for the determination of MBT and the certified value (450 ng/g $\pm 50 \mathrm{ng} / \mathrm{g}$ as $\mathrm{Sn}$ ) for this reference sediment has been shown to be debatable by a number of independent publications (Chiron et al., 2000; Rodriguez-Gonzalez et al., 2003). The actual MBT content appears to be closer to $600 \mathrm{ng} / \mathrm{g}$ although this compound has not yet been re-certified. The MBT recovery 
compared to the certified value was low (52\%) and compared to the value quoted in the literature a mean recovery of $\sim 40 \%$ was obtained for this compound. Based on this data a recovery correction factor of 2.5 for MBT was used for data reported in this work, and results obtained for DBT and TBT by SS-IDMS were not corrected for recoveries.

\section{Results and Discussion}

Results are presented as concentrations of butyltin species as ng (as Sn)/g dry weight of sediment with core depths related to OD used to give a baseline from where sediment deposition began. The sediment surface at the point the core was extracted from was at $-0.53 \mathrm{~m}$ relative to OD and exposed at low tide. Butyltin species were detected throughout the sediment core, with the exception of two samples at the base, which consisted of clay (974-984 and 1013-1023) rather than more geologically recent sediment (Table 2). In most samples tributyltin (TBT) accounted for $<10 \%$ of the total butyltin present, in contrast to other work which has reported TBT accounting for approximately $50 \%$ of the total in sediments from the river Thames (Harino et al., 2003). Although the TBT concentrations reported by Harino et al. (2003), of $11 \mathrm{ng} / \mathrm{g}$ as Sn at Tilbury agree relatively well with TBT concentrations in this work, the difference in percentage contribution to the total is because both mono and dibutyl tin concentrations reported here are significantly (10 to 20 times) greater. However, Harino et al. (2003) sampled surficial sediments, and not core samples which were used in this study which began at a depth $15 \mathrm{~cm}$ below the sediment surface, and continued down to below $10 \mathrm{~m}$. When comparison is made with data from other sediment cores, then the relative proportions of mono- and dibutyl tin have been observed to increase in a similar manner, with samples dating back to 1977 having as little as $10 \%$ of total butyltin as TBT (Sarradin et al., 1995), as observed in this work (Table 2).

The relationship between depth of sediment samples in the Tilbury core and date has previously been elucidated from soundings data and also the changes in sewage effluent quality associated with the commissioning of secondary wastewater treatment plants at Beckton and Crossness during the 1960s. This resulted in improvements in river water quality and a reduction in concentrations of contaminants associated with the sediments (Scrimshaw and Lester, 1997; Wiese et al., 1997). This is illustrated in Fig. 2, where the concentration of total butyltin species is compared to that of polychlorinated biphenyls.

Radiometric dating techniques, using ${ }^{210}$ Po activity, have been used to determine sedimentation rates in environments such as saltmarsh sediments (Cundy and Croudace, 1995), however, at sites impacted by anthropogenic activity, the use of models and reference to supporting data from 
records of artificial fallout radionuclides $\left({ }^{137} \mathrm{Cs}\right.$ or $\left.{ }^{241} \mathrm{Am}\right)$ are required to calculate chronology (Appleby, 2000). Therefore, due to the known activities at the site, and evidence of re-working from depth changes between 1976 and 1980 (Fig. 2), the use of such techniques on the cores from Tilbury were deemed inappropriate. Dating of the core was undertaken by studying dredging records, and a number of inferences could be drawn from the soundings charts studied. In 1916 the Basin was dredged to depths of $-9.0 \mathrm{~m}$ to $-10.5 \mathrm{~m}$ (all depths are relative to OD). Dredging was less extensive after 1944, with surveys showing depths of around $-6.6 \mathrm{~m}$, although the basin may have been dredged to greater depths than this with subsequent rapid accretion before soundings were taken. The last occasion that surveys recorded a significant decrease in depth was between December 1965 (-4.3 m) and January 1966 when levels fell to $-5.3 \mathrm{~m}$ although dredging could have been to greater depths. These are average levels, with an estimated error of $\pm 0.4 \mathrm{~m}$. Dredging then ceased and the level of sediment deposits in the Basin exhibited a rapid rise to $-2.5 \mathrm{~m}( \pm 0.2$ m) by October 1966 and subsequently sediments accreted at a much reduced rate. Certainly between 1976 and 1980, it would appear that some re-working may have occurred (Fig. 2), although subsequently, as sediment accreted, concentrations of butyltins have exhibited a decline, possibly as a result of restrictions on their use on vessels of $<25 \mathrm{~m}$ length introduced in the UK in 1985 (de Mora, 1996). Because no record was kept of the depth to which the Basin was actually dredged, and that more recent dredging may have extended to greater depths than previous dredges, it has only been possible to conclude that material deposited above $-5.3 \mathrm{~m}$ dates from post January 1966, and that material below this depth must pre-date that. However, with the additional information on TBT concentrations, and the knowledge that the use of trialkyl compounds did not come into use as anti-foulants in Europe until 1959 - 1961 (Clark et al., 1988), the presence of butyltin species, including tributyl tin residues, in the sediments would imply that deposition of material between $-9.5 \mathrm{~m}$ and $-5.3 \mathrm{~m}$ occurred after 1959 and ended with the dredging event of January 1965.

Inputs of PCB (and organochlorine compounds and heavy metals) to the sediments were relatively constant before 1966 (Fig. 2) and the most probable source of these compounds has been identified as the sewage treatment works (STW) at Beckton and Crossness (Scrimshaw and Lester, 1997; Wiese et al., 1997). It had been assumed that a single event of rapid accretion had possibly occurred at depths below $-5.3 \mathrm{~m}$ OD. The data for organotin compounds does not, 
however, support this interpretation of a single event of rapid accretion at depths below $-5.3 \mathrm{~m}$ OD. Had all this sediment been deposited over a short time (a matter of months), then concentrations with depth, relating to temporal inputs over a short time, would be expected to show little variation as would the relative proportions of degradation products. It is apparent from Fig. 3 that the proportion of degradation products (DBT and MBT) relative to the parent tributyl compound is not constant in the section of the core deeper than $-5.3 \mathrm{~m}$, although the clear difference in proportions present above and below $-5.3 \mathrm{~m}$ would support the hypothesis that sediments in these two sections of the core were deposited at different times as a result of dredging activities. However, total organotin concentration was observed to increase in samples from between approx. $-9.5 \mathrm{~m}$ OD to $-5.3 \mathrm{~m}$ OD (Fig. 2), which may reflect the increase in use of TBT, most probably as an antifoulant, from 1959/1961 to the mid 1960s. It is unlikely that the STW were a major source of butyltin compounds, as it would be expected that introduction of secondary treatment would have resulted in a significant decrease in inputs similar to that observed for organochlorine compounds (Fent and Muller, 1991; Fent, 1996).

Rate constants for the degradation of TBT have been calculated by a number of workers, and a value of $\mathrm{k}=0.35$ / year would be a reasonable estimate for residues in anaerobic sediments (Dowson et al., 1993; Sarradin et al., 1995). Substitution of this constant into equation 1, along with the average concentration of TBT, [TBT], from the Tilbury core at depths 7.39-9.45 $\mathrm{m}$ (4.15 $\mathrm{ng} / \mathrm{g}$ ) and an estimated maximum age of these samples at the time the core was taken (1994) (t) of 34 years, it is possible to estimate the TBT concentration $\left[\mathrm{T}_{0}\right]$ at the time the sediment was deposited (1960).

$$
\ln \left[\mathrm{T}_{0}\right]=\ln [\mathrm{TBT}]+\mathrm{k} . \mathrm{t}
$$

This calculation estimates that the concentration of TBT would have been around $600 \mu \mathrm{g} / \mathrm{g}$ and applying the same rationale to samples from $4.94-7.00 \mathrm{~m}$, but dating at the minimum age (1966) of 28 years would indicate contamination at the time of deposition being $430 \mu \mathrm{g} / \mathrm{g}$ TBT. These values are in good agreement with each other, and may well represent a first estimate of TBT concentrations in River Thames sediments during the early 1960s. The values also fall well within the range of concentrations ( 10 to $10,000 \mu \mathrm{g} / \mathrm{g}$ ) reported as being observed in harbour sediments (Hoch, 2001). 
It is apparent that residues of butyltin species remain at depth in the sediments over 30 years after deposition, which reflects the long half lives of these compounds in anaerobic conditions. Their presence in sediments may in itself not be an immediate problem, however, if material is disturbed it may result in subsequent desorption of bound contaminants to the water column where they will be more readily bioavailable (Batley, 1996). The binding of organotin species to sediments has been demonstrated to be a reversible process involving particulate organic matter in the sediments and desorption occurs readily. As a consequence, disturbance of contaminated sediments is likely to result in an increase in organotin concentrations in the water column, although if undisturbed contaminated sediments are unlikely to be an input source (Berg et al., 2001). However, laboratory studies have indicated that sediment bound TBT may not be as available as new inputs and that the development of pollution induced community tolerance may result from long-term exposure to contaminated sediments (Dahllof et al., 2001).

In the longer term, reworking of sediment bound TBT may become a more significant source of inputs than from freshly applied antifoulant paints. The adoption by the International Maritime Organization in October 2001 of a worldwide ban on the use of TBT on shipping from January 2003 should reduce fresh inputs to marine and estuarine environments (IMO, 2003). However, the use of alternative biocides to TBT may not resolve all environmental issues associated with antifouling treatments. Residues of some active ingredients from replacement treatments used on smaller $(<25 \mathrm{~m})$ boats have been found in UK waters and sediments (Voulvoulis et al., 2000; Thomas et al., 2001) although a comparative assessment of environmental effects of the replacement compounds in relation to TBT indicated that they would be less harmful (Voulvoulis et al., 2002).

The presence, fate and long-term behavior of TBT and other butyltin compounds in sediments is an issue of concern worldwide (Bhosle et al., 2004; Sudaryanto et al., 2004) with occurrence of imposex continuing to be reported (Fernandez et al., 2005). The importance of generating further data on TBT for use in developing models for understanding the mass balance of priority contaminants within water bodies of has recently been highlighted by studies focused on the Great Lakes (Booty et al., 2005) and field based data such as presented in this work should compliment laboratory based studies where factors influencing the sorption and desorption of TBT continue to be evaluated (Burton et al., 2004).

\section{Conclusions}


It is possible to construct a hypothesis for the historical deposition of TBT contaminated sediment at Tilbury which is consistent with the interpretation of data obtained for organochlorine compounds ate metallic elements. In fact, the results of analysis for TBT indicate some stratification is present in the section of the core at depths below $-5.3 \mathrm{~m}$ which was not apparent before.

Use of the degradation rate constant (k) of 0.35 / year as derived by other workers would indicate that historical contamination with TBT was in the order of $430-600 \mu \mathrm{g} / \mathrm{g}$, which is within reported ranges for TBT concentrations in other harbor sediments.

These findings are demonstrate that TBT residues persist in anaerobic sediments for a significant period and other data indicates that remobilization may introduce bioavailable inputs of TBT to the environment which may become relatively more significant as the ban on TBT use comes into effect.

\section{Acknowledgements}

The analytical work carried out at LGC Ltd. during this collaborative project was funded under contract with the Valid Analytical Measurement (VAM) programme of the Department for Trade and Industry (DTI) UK. The authors wish to thank the Royal Society for financial support and the the Port of Tilbury (London) Ltd and British Geological Survey for their assistance and advice in obtaining the core.

\section{References}

Almeida, A. C., Wagener, A. D. R., Maia, C. B. and Miekeley N. 2004. Speciation of organotin compounds in sediment cores from Guanabara Bay, Rio de Janeiro (Brazil) by gas chromatography-pulsed flame photometric detection. Applied Organometallic Chemistry 18, 694-704.

Alzieu, C. 1991. Environmental-Problems Caused By TBT In France - Assessment, Regulations, Prospects. Marine Environmental Research 32, 7-17.

Alzieu, C. 2000. Environmental impact of TBT: the French experience. Science of the Total Environment 258, 99-102.

Appleby, P. G. 2000. Radiometric dating of sediment records in European mountain lakes. Journal of Limnology 59, (Suppl. 1), 1-14.

Bartlett, A. J., Borgmann, U., Dixon, D. G., Batchelor, S. P. and Maguire, R. J. 2004. Accumulation of tributyltin in Hyalella azteca as an indicator of chronic toxicity: Survival, growth, and reproduction. Environmental Toxicology and Chemistry 23, 2878-2888.

Batley, G. (1996). Distribution and fate of tributyltin in the marine environment. Tributyltin: Case Study of an Environmental Contaminant. S. J. de Mora. Cambridge, Cambridge University Press: $139-166$.

Bennett, R. F. 1983. Industrial development of organotin chemicals. Industrial Chemistry Bulletin 2, 171-176. 
Berg, M., Arnold, C. G., Muller, S. R., Muhlemann, J. and Schwarzenbach, R. P. 2001. Sorption and desorption behavior of organotin compounds in sediment-pore water systems. Environmental Science \& Technology 35, 3151-3157.

Bhosle, N. B., Garg, A., Jadhav, S., Harjee, R., Sawant, S. S., Venkat, K. and Anil, A. C. 2004. Butyltins in water, biofilm, animals and sediments of the west coast of India. Chemosphere 57, 897-907.

Blunden, S. J. and Chapman, A. H. 1982. The environmental degradation of organotin compounds - A review. Environmental Technology Letters 3, 267-272.

Broodbank, Sir J. G. (1921). The History of the Port of London, Volumes 1 and 2. Daniel Connor, London, $515 \mathrm{pp}$.

Burton, E. D., Phillips, I. R. and Hawker, D. W. 2004. Sorption and desorption behavior of tributyltin with natural sediments. Environmental Science and Technology 38, 6694-6700.

Chiron, S., Roy, S., Cottier, R. and Jeannot, R. 2000. Speciation of butyl- and phenyltin compounds in sediments using pressurized liquid extraction and liquid chromatographyinductively coupled plasma mass spectrometry. Journal of Chromatography A 879, 137-145.

Clark, E. A., Sterritt, R. M. and Lester, J. N. 1988. The Fate of Tributyltin in the Aquatic Environment - a Look at the Data. Environmental Science \& Technology 22, 600-604.

Cundy, A. B. and Croudace, I. W. 1995. Sedimentary and geochemical variations in a salt marsh/mud flat environment from the mesotidal Hamble Estuary, southern England. Marine Chemistry 51, 115-132.

Dahllof, I., Agrenius, S., Blanck, H., Hall, P., Magnusson, K. and Molander, S. 2001. The effect of TBT on the structure of a marine sediment community - a boxcosm study. Marine Pollution Bulletin 42, 689-695.

de Mora, S. J. (1996). The tributyltin debate: ocean transportation versus seafood harvesting. Tributyltin: Case Study of an Environmental Contaminant. S. J. de Mora. Cambridge, Cambridge University Press: 1-20

Dowson, P. H., Bubb, J. M. and Lester, J. N. 1993. Temporal distribution of organotins in the aquatic environment: five years after the 1987 UK retail ban on TBT based antifouling paints. Marine Pollution Bulletin 26, No.9, 487-494.

Dowson, P. H., Bubb, J. M. and Lester, J. N. 1994. The Effectiveness Of the 1987 Retail Ban On Tbt Based Antifouling Paints In Reducing Butyltin Concentrations In East-Anglia, Uk. Chemosphere 28, 905-910.

Dowson, P. H., Bubb, J. M. and Lester, J. N. 1996. Persistence and Degradation Pathways Of Tributyltin In Fresh-Water and Estuarine Sediments. Estuarine Coastal and Shelf Science 42, 551-562.

Dowson, P. H., Bubb, J. M., Williams, T. P. and Lester, J. N. 1993. Degradation Of Tributyltin In Fresh-Water and Estuarine Marina Sediments. Water Science and Technology 28, 133-137.

Evans, S. M., Evans, P. M. and Leksono, T. 1996. Widespread Recovery Of Dogwhelks, NucellaLapillus (L), From Tributyltin Contamination In the North-Sea and Clyde-Sea. Marine Pollution Bulletin 32, 263-269.

Fernandez, M. A., Wagener, A. D. R., Limaverde, A. M., Scofield, A. L., Pinheiro, F. M. and Rodrigues, E. 2005. Imposex and surface sediment speciation: A combined approach to evaluate organotin contamination in Guanabara Bay, Rio de Janeiro, Brazil. Marine Environmental Research 59, 435-452.

Fent, K. 1996. Organotin compounds in municipal wastewater and sewage sludge: contamination, fate in treatment process and ecotoxicological consequences. Science of the Total Environment 185, No.1/3, 151-159. 
Fent, K. and Muller, M. D. 1991. Occurrence of organotins in municipal wastewater and sewage sludge and behaviour in a treatment plant. Environmental Science \& Technology 25, No.3, 489-493.

Greeves, I. S. (1980). London Docks 1800-1980. A Civil Engineering History. Thomas Telford Ltd., London, $155 \mathrm{pp}$

Harino, H., O'Hara, S. C. M., Burt, G. R., Chesman, B. S., Pope, N. D. and Langston, W. J. 2003. Organotin compounds in Mersey and Thames Estuaries a decade after UK TBT legislation. Journal of the Marine Biological Association of the United Kingdom 83, 11-22.

Hoch, M. 2001. Organotin compounds in the environment -- an overview. Applied Geochemistry $16,719-743$.

Horiguchi, T., Li, Z., Uno, S., Shimizu, M., Shiraishi, H., Morita, M., Thompson, J. A. J. and Levings, C. D. 2004. Contamination of organotin compounds and imposex in molluses from Vancouver, Canada. Marine Environmental Research 57, 75-88.

IMO (2003). International Convention on the Control of Harmful Anti-Fouling Systems on Ships, 2001 (AFS 2001). London, International Maritime Organisation.

Jones, M. A., Stauber, J., Apte, S., Simpson, S., Vicente-Beckett, V., Johnson, R. and Duivenvoorden L. 2005. A risk assessment approach to contaminants in Port Curtis, Queensland, Australia. Marine Pollution Bulletin 51, 448-458.

Midorikawa, S., Arai, T., Harino, H., Ohji, M., Cu, N. D. and Miyazaki, N. 2004. Concentrations of organotin compounds in sediment and clams collected from coastal areas in Vietnam. Environmental Pollution 131, 401-408.

Ramaswamy, B. R., Tao, H. and Hojo, M. 2004. Contamination and biomethylation of organotin compounds in pearl/fish culture areas in Japan. Analytical Sciences 20, 45-53.

Randall, L. and Weber, J. H. 1986. Adsorptive Behavior of Butyltin Compounds under Simulated Estuarine Conditions. Science of the Total Environment 57, 191-203.

Rodriguez-Gonzalez, P., Encinar, J. R., Alonso, J. I. G. and Sanz-Medel, A. 2003. Isotope dilution analysis as a definitive tool for the speciation of organotin compounds. Analyst 128, 447-452.

Sarradin, P. M., Lapaquellerie, Y., Astruc, A., Latouche, C. and Astruc, M. 1995. Long-Term Behavior and Degradation Kinetics Of Tributyltin In a Marina Sediment. Science of the Total Environment 170, 59-70.

Scrimshaw, M. D. and Lester, J. N. 1997. Estimates of the inputs of polychlorinated biphenyls and organochlorine insecticides to the River Thames derived from the sediment record. Philosophical Transactions of the Royal Society of London A 355, 189-212.

Smith, L. D., Negri, A. P., Philipp, E., Webster, N. S. and Heyward, A. J. 2003. The effects of antifoulant-paint-contaminated sediments on coral recruits and branchlets. Marine Biology 143, 651-657.

Sturgeon, R. E. and Wahlen, R. 2002. Pilot Study: CCQM-P18: Tributyltin in sediment. Metrologia 39, Tech. Suppl. 08003, 08003-1-17.

Sturgeon, R. E., Wahlen, R., Brandsch, T., Fairman, B., Wolf-Briche, C., Alonso, J. I. G., Gonzaalez, P. R., Encinar, J. R., Sanz-Medel, A., Inagaki, K., Takatsu, A., Lalere, B., Monperrus, M., Zuloaga, O., Krupp, E., Amouroux, D., Donard, O. F. X., Schimmel, H., Sejeroe-Olsen, B., Konieczka, P., Schultze, P., Taylor, P., Hearn, R., Mackay, L., Myors, R., Win, T., Liebich, A., Philipp, R., Yang, L. and Willie, S. 2003. Determination of tributyltin in marine sediment: Comite Consultatif pour la Quantite de Matiere (CCQM) pilot study P-18 international intercomparison. Analytical and Bioanalytical Chemistry 376, 780-787.

Sudaryanto, A., Takahashi, S., Iwata, H., Tanabe, S. and Ismail, A. 2004. Contamination of butyltin compounds in Malaysian marine environments. Environmental Pollution 130, 347358. 
Thomas, K. V., Fileman, T. W., Readman, J. W. and Waldock, M. J. 2001. Antifouling Paint Booster Biocides in the UK Coastal Environment and Potential Risks of Biological Effects. Marine Pollution Bulletin 42, 677-688.

Unger, M. A., Macintyre, W. G. and Huggett, R. J. 1988. Sorption Behavior of Tributyltin on Estuarine and Fresh-Water Sediments. Environmental Toxicology and Chemistry 7, 907-915.

Highly persistent butyltins in northern marine sediments: A longterm threat for the Saguenay Fjord (Canada)

Viglino, L., Pelletier, E. and St-Louis R. 2004. Highly persistent butyltins in northern marine sediments: A longterm threat for the Saguenay Fjord (Canada). Environmental Toxicology and Chemistry 23, 2673-2681.

Voulvoulis, N., Scrimshaw, M. D. and Lester, J. N. 2000. Occurrence of four biocides utilized in antifouling paints, as alternatives to organotin compounds, in waters and sediments of a commercial estuary in the UK. Marine Pollution Bulletin 40, 938-946.

Voulvoulis, N., Scrimshaw, M. D. and Lester, J. N. 2002. Comparative environmental assessment of biocides used in antifouling paints. Chemosphere 47, 789-795.

Wahlen, R. and Wolff-Briche, C. 2003. Comparison of GC-ICP-MS and HPLC-ICP-MS for species-specific isotope dilution analysis of tributyltin in sediment after accelerated solvent extraction. Analytical and Bioanalytical Chemistry 377, 140-148.

Wiese, S. B. O., MacLeod, C. L. and Lester, J. N. 1997. A recent history of metal accumulation in the sediments of the Thames Estuary, United Kingdom. Estuaries 20, 483-493. 
Figure captions

Fig. 1. Location of Tilbury Docks on the River Thames, in relation to central London (London Bridge), the tidal limit at Teddington Weir and major sewage treatment works.

Fig. 2. Comparison of sediment concentrations of total butyltin and polychlorinated biphenyl concentrations (Scrimshaw and Lester, 1997) with depth obtained from soundings data. Dates indicate that sediments below the line must be older than the most recent value given.

Fig. 3. Increase in concentrations of DBT and MBT relative to that of TBT with depth. Trendlines for DBT/MBT (_ $)$ and MBT/TBT (-----) 


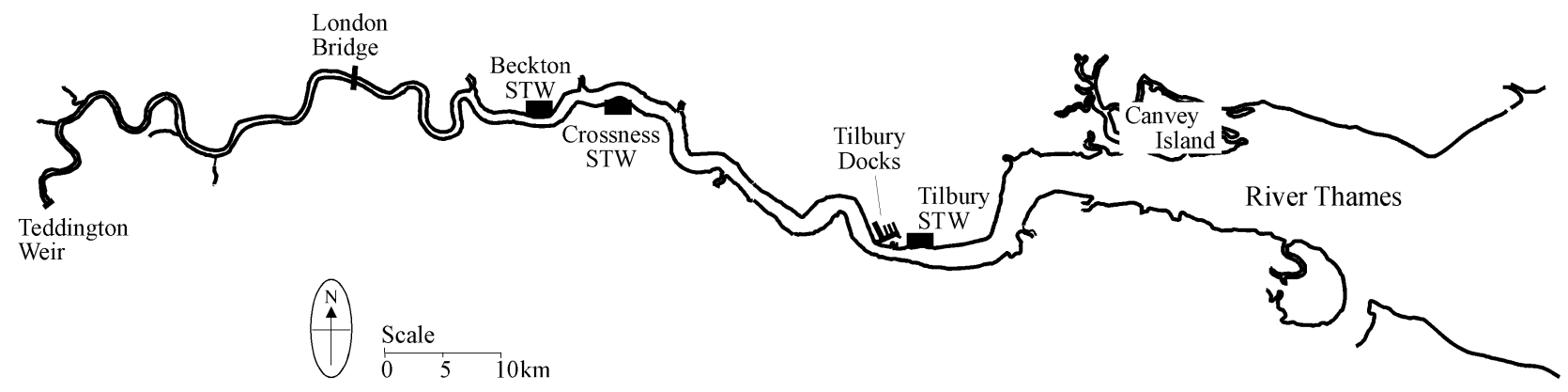

Fig. 1. Location of Tilbury Docks on the River Thames, in relation to central London (London Bridge), the tidal limit at Teddington Weir and major sewage treatment works. 


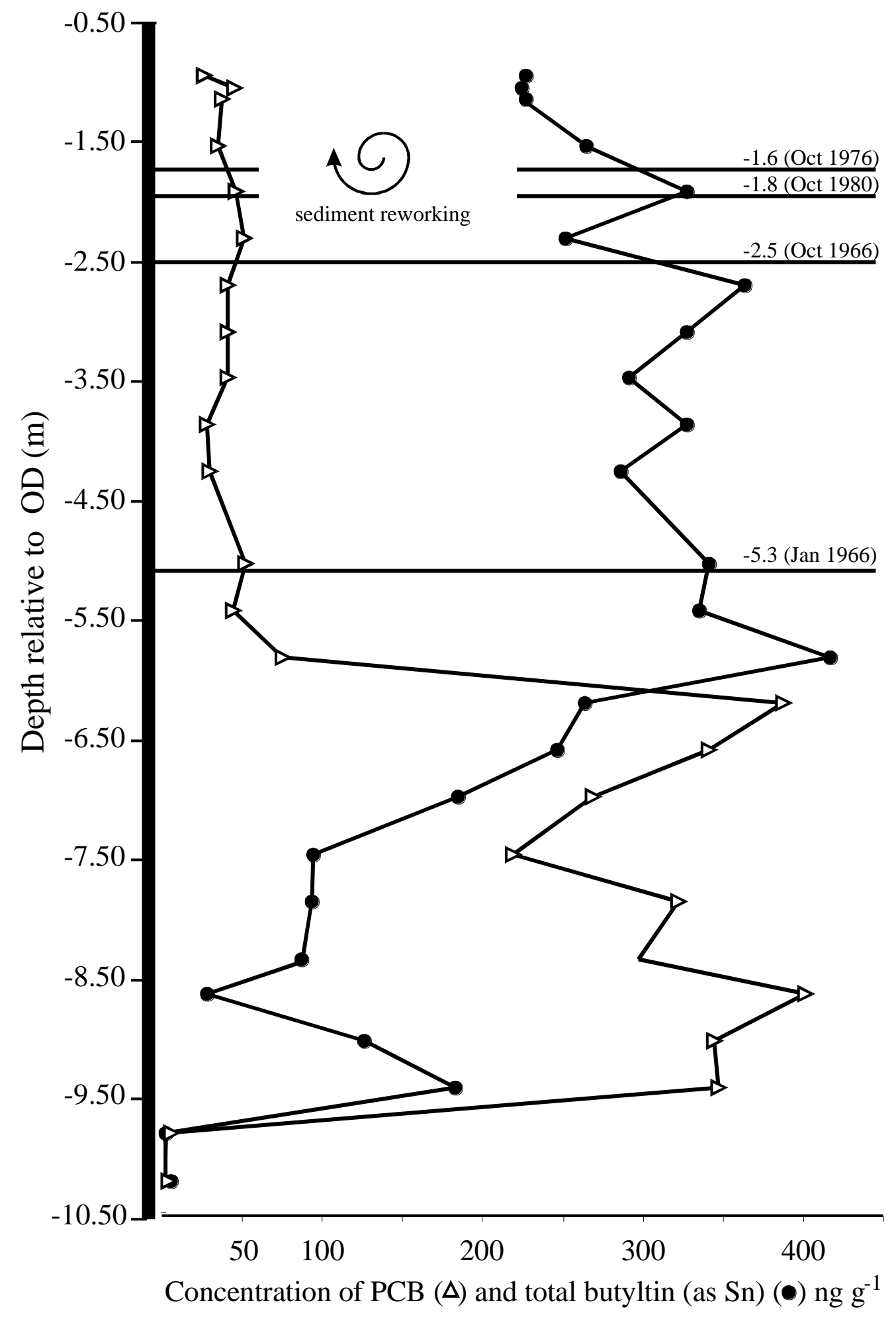

Fig. 2. Comparison of sediment concentrations of total butyltin and polychlorinated biphenyl concentrations (Scrimshaw and Lester, 1997) with depth obtained from soundings data. Dates indicate that sediments below the line must be older than the most recent value given. 


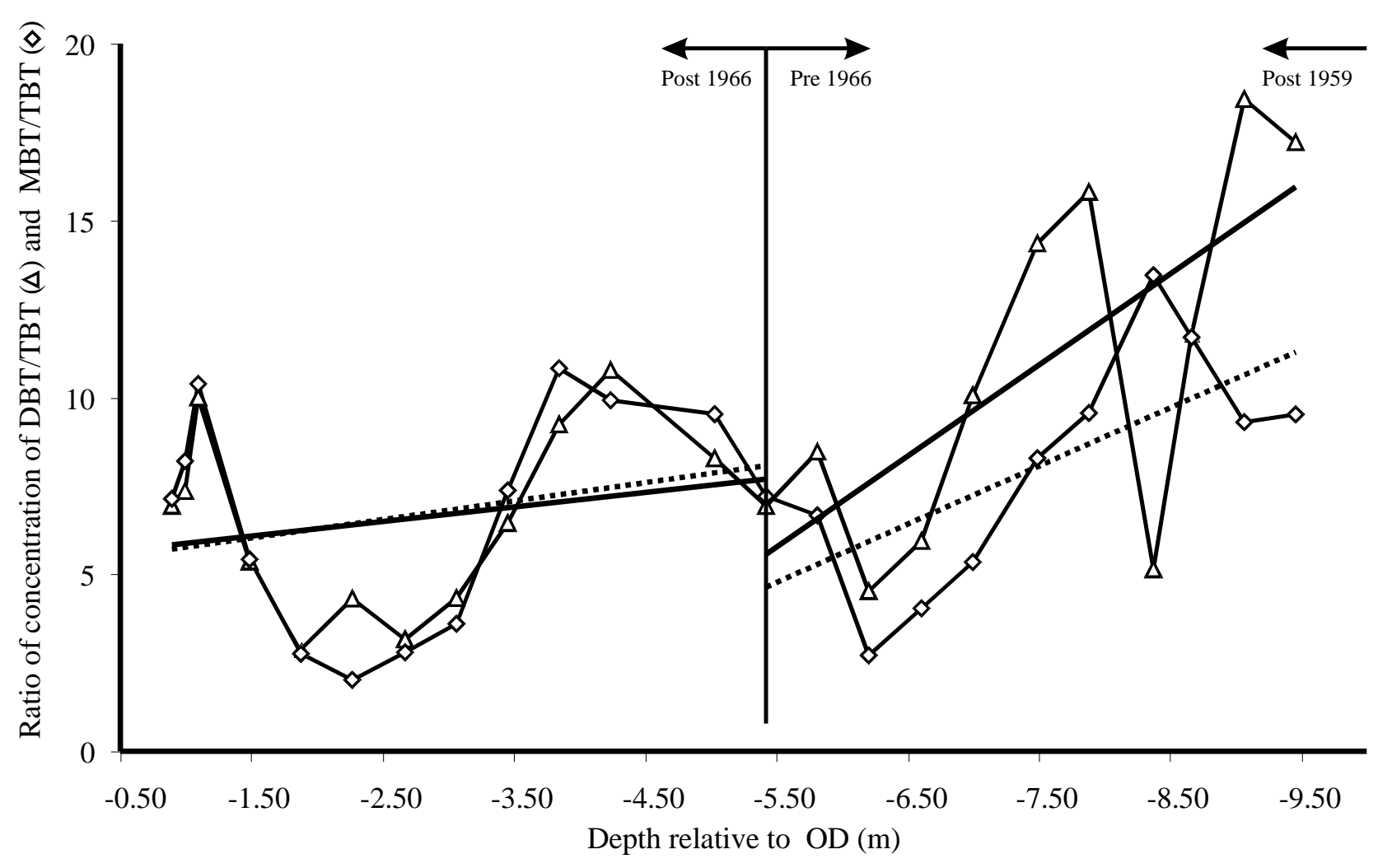

Fig. 3. Increase in concentrations of DBT and MBT relative to that of TBT with depth. Trendlines for DBT/MBT (- - and MBT/TBT (-----) 
Table 1. Concentrations of MBT, DBT and TBT determined in PACS-2 (ng/g as Sn).

\begin{tabular}{lccc}
\hline Replicate & MBT & DBT & TBT \\
\hline 1 & 239 & 1014 & 875 \\
2 & 235 & 966 & 885 \\
3 & 231 & 993 & 862 \\
Mean & 235 & 991 & 874 \\
SD & 4 & 24 & 12 \\
Recovery (\%) & 52 & 91 & 89 \\
\hline
\end{tabular}


Table 2. Sediment concentrations of MBT, DBT and TBT (ng/g dry weight as Sn)

\begin{tabular}{|c|c|c|c|c|c|}
\hline $\begin{array}{l}\text { Estimated } \\
\text { date }\end{array}$ & Depth $<$ OD (m) & MBT (\% rsd) & DBT (\% rsd) & TBT (\% rsd) & $\begin{array}{c}\text { Total } \\
\text { organotin }\end{array}$ \\
\hline & $0.82-0.92$ & $110(1.0)$ & $107(4.4)$ & $17(0.4)$ & 234 \\
\hline & $0.92-1.02$ & $116(1.2)$ & $103(0.7)$ & $15(0.9)$ & 234 \\
\hline \multirow{4}{*}{$\begin{array}{l}1975 \\
1980\end{array}$} & o $1.02-1.12$ & $115(1.2)$ & $110(0.7)$ & $12(0.4)$ & 237 \\
\hline & $1.41-1.51$ & $120(1.3)$ & $119(1.2)$ & $24(0.6)$ & 264 \\
\hline & $1.80-1.90$ & $131(3.5)$ & $138(4.4)$ & $58(2.1)$ & 326 \\
\hline & $2.20-2.29$ & $60(3.8)$ & $150(2.0)$ & $39(0.5)$ & 250 \\
\hline \multirow[t]{4}{*}{ Late 1966} & $2.59-2.69$ & $140(3.4)$ & $162(2.7)$ & $60(0.2)$ & 363 \\
\hline & $2.98-3.08$ & $128(0.6)$ & $157(1.8)$ & $41(1.4)$ & 326 \\
\hline & $3.37-3.47$ & $144(0.1)$ & $125(2.8)$ & $21(3.0)$ & 290 \\
\hline & $3.76-3.86$ & $168(0.9)$ & $142(0.2)$ & $16(1.7)$ & 327 \\
\hline Post $1966 \uparrow$ & $4.16-4.25$ & $130(0.1)$ & $142(0.4)$ & $14(1.5)$ & 285 \\
\hline \multirow[t]{11}{*}{ Pre-1966 $\downarrow$} & $4.94-5.04$ & $172(0.4)$ & $149(0.2)$ & $19(1.5)$ & 340 \\
\hline & $5.33-5.43$ & $158(1.2)$ & $152(0.7)$ & $24(3.3)$ & 334 \\
\hline & $5.72-5.82$ & $170(1.9)$ & $219(2.4)$ & $28(3.3)$ & 416 \\
\hline & $6.12-6.21$ & $81(1.5)$ & $146(3.2)$ & $36(0.6)$ & 263 \\
\hline & $6.51-6.61$ & $87(1.2)$ & $134(2.0)$ & $25(1.2)$ & 245 \\
\hline & $6.90-7.00$ & $58(0.0)$ & $114(6.3)$ & $12(3.6)$ & 183 \\
\hline & 7.39-7.49 & $32(1.7)$ & $57(0.7)$ & $4(0.0)$ & 93 \\
\hline & $7.78-7.88$ & $33(0.5)$ & $55(0.6)$ & $4(1.9)$ & 91 \\
\hline & $8.27-8.37$ & $62(1.8)$ & $22(1.6)$ & $5(4.0)$ & 89 \\
\hline & $8.57-8.66$ & $12(0.0)$ & $12(2.3)$ & $1(0.0)$ & 26 \\
\hline & $8.96-9.06$ & $40(3.1)$ & $81(0.8)$ & $5(1.6)$ & 125 \\
\hline Post $1959 \uparrow$ & $\uparrow 9.35-9.45$ & $61(2.3)$ & $113(1.2)$ & $7(2.1)$ & 182 \\
\hline Clay & $9.74-9.84$ & n.d. & n.d. & n.d. & 0 \\
\hline Clay & $10.13-10.23$ & n.d. & n.d. & n.d. & 0 \\
\hline
\end{tabular}

